\title{
Motivation for Parenthood among LGBTIQ People in Croatia: Reasons for (not) Becoming a Parent
}

DOI: $10.5613 /$ rzs.49.2.2

UDK: 316.644(497.5):316.362.34(497.5)

316.361.15(497.5)

Izvorni znanstveni rad

Primljeno: 18. 1. 2019.

\section{Marina ŠTAMBUK}

Department of Management and Rural Entrepreneurship, Faculty of Agriculture, University of Zagreb, Croatia

mstambuk@agr.hr

Marina MILKOVIĆ

Centre for Social Welfare Zagreb, Subsidiary Gornji grad - Medveščak, Zagreb, Croatia

marinamilkovic88@gmail.com

Antonija MARIČIĆ

Zagreb, Croatia

antonija.maricic@gmail.com

\section{ABSTRACT}

Parenting desires, intentions, and the underlying motivation for parenthood are well documented in the context of heterosexual couple parenthood, while among lesbian, gay, bisexual, transgender, intersex and queer (LGBTIQ) people research is limited. The main goal of this study was to explore parenting desire and different reasons to become a parent or remain childfree among LGBTIQ people in Croatia. 486 childless LGBTIQ people participated in an on-line survey. In the quantitative part of the study, parenting desire and reasons for and against parenthood were measured, while the qualitative part analysed the answers to open-ended questions about additional reasons that influence the desire to want or not to want children. The results showed that $46 \%$ of the participants want to become parents, $35 \%$ did not know, and 19\% reported they do not want to have children. The main reasons for parenthood among the participants who want children were internal - the desire to give love, share knowledge, and develop a special bond with a child. The participants who do not want to have children also stressed internal reasons against parenthood, such as restricted personal freedom, high responsibility, and the amount of workload they perceive as a part of parenthood. Several additional reasons for and against parenthood emerged from the qualitative data. Some reasons reflected universal issues unrelated to sexual orientation or gender identity, while others conveyed concerns related to social and legal barriers that LGBTIQ people face when it comes to parenthood.

Key words: parenting desires, reasons for parenthood, reasons against parenthood, LGBTIQ people 


\section{INTRODUCTION}

Why people are less likely to have children and what is their motivation to become parents or remain childfree have been crucial issues for understanding the changes in demographic trends in contemporary Western societies. Research on this topic was mostly done among heterosexual and cisgender people, ${ }^{1}$ although parenting desire and parenthood are not only reserved for those couples or individuals. People who identify as lesbian, gay, bisexual, transgender, intersex, or queer $\left(\mathrm{LGBTIQ}^{2}\right)$ also want to become parents or already are parents.

Traditionally, the research on parenthood that included LGBTIQ people was mainly focussed on whether parental sexual orientation harms children's development. Contrary to common prejudice, there is a lack of evidence that lesbian women or gay men are unfit to be parents and that the psychosocial development of their children is compromised relative to the children of heterosexual parents (e.g. Golombok, 2017; Vučković Juroš, 2017). Similarly, having a transgender parent was not found to affect a child's gender identity or sexual orientation, nor to have a negative impact on other developmental milestones (Stotzer, Herman and Hasenbush, 2014).

In contemporary studies, the research interest shifted to parenthood motivation and the decision-making processes about whether to become a parent or remain childfree. These topics are still understudied worldwide, especially in the contexts outside of North America and Western Europe. Therefore, this study aims to broaden our understanding of the reasons for and against parenthood among LGBTIQ people in Croatia, where legal barriers to parenthood for same-sex couples are still strong, and where prejudice and discrimination based on sexual orientation and gender identity are common (European Union Agency for Fundamental Rights, 2014; Huić, Jugović and Kamenov, 2015; Kamenov, Huić and Jelić, 2019; Vučković Juroš, Dobrotić and Zrinščak, 2015; Vučković Juroš, 2019).

\subsection{Parenthood motivation}

Despite the increasing number of people in the Western countries who choose to remain childfree or delay parenthood, becoming a parent is still an important life goal for most women and men (Thornton and Young-DeMarco, 2001; Weston et

\footnotetext{
$1 \quad$ Cisgender is a term describing people whose gender identity matches the sex they were assigned at birth.

2 The abbreviation LGBTIQ is used generically in this paper when we do not refer to a specific study. When we do, we use appropriate abbreviations according to participants' identity.
} 
al., 2004). The results of studies on parenting desires ${ }^{3}$ and intentions in emerging adulthood show that only $15 \%$ or fewer participants do not want or do not plan to have children in the future (Hanzec Marković and Štambuk, 2019; Lampic et al., 2006; Thompson and Lee, 2011; Tydén et al., 2006). Parenting desires and intentions are shown to be crucial in predicting parenting behaviours (Freitas and Testa, 2017; Miller and Pasta, 1996); however, our understanding of the underlying reasons is quite limited.

One of the pioneers in this area of research was Rabin (1965) who differentiated the altruistic, fatalistic, narcissistic, and instrumental parenthood motivation. Further on, Hoffman and Hoffman (1973) developed a theoretical scheme for the value of children in terms of psychological needs they satisfy in their parents. Hoffman, Thorton and Manis (1978) showed that the two most commonly expressed values were categorised as Primary group ties and Stimulation and fun. Langdridge, Connolly and Sheeran (2000) found that the participants explained the decision to become parents with internal reasons similar to the most prominent values of children described by Hoffman et al. (1978). The most important reasons for parenthood were the need to give and receive love as well as experience of the fulfilment and enjoyment of having children. Further, the participants expressed the wish to create something that is a part of both partners and to become a family. The same authors (Langdridge, Sheeran and Connolly, 2005) were the first to explore not only the motivation for parenthood but also the reasons why individuals do not want to have children in relation to parenthood intention. In their research intenders and non-intenders differed significantly in all reasons for and against having a child except one - the risk of having a disabled child.

Recently, Langdridge and colleagues' (2005) lists of reasons were used in Sweden on a sample of young adult men (Thompson and Lee, 2011) and in Croatia among the participants in emerging adulthood (18 to 30 years of age; Hanzec Marković and Štambuk, 2019). In these studies, the most important reasons for parenthood among the participants who wanted to have children were the need to give and receive love, develop a special bond with a child, share knowledge, experience fulfilment through child-raising, and give a good home to a child. The most important reasons against parenthood among the participants that reported not wanting to have children included restrictions of personal freedom, refusal of responsibility, and the belief that bringing up a child is too difficult. In addition, the participants reported that they wanted to remain childfree because there were oth-

In this research area the term fertility desire/intention/decision is usual. However, this term has a biological connotation and is more appropriate for literature on heterosexual parenthood. Thus, in our research we use parenting desire/intention/decision, a concept with a wider meaning covering different pathways to parenthood, including non-biological ones (Kranz, Busch and Niepel, 2018). 
er more important things in life, that they would not be good at parenthood, and that they believed parenthood would negatively affect their career and partnership. Similar findings were reported in Swedish studies on the consequences of parenthood (Lampic et al., 2006; Tydén et al., 2006). In these studies, the majority of university students reported that they believed becoming a parent would lead to personal development, giving and receiving more love, and obtaining another view on what is important in life. As for the negative consequences of parenthood, participants emphasised the restriction of freedom and less time to devote to work, career, and personal interests, along with financial problems.

In most of the previous research, participants' sexual orientation was ignored or presumed based on the gender of a participant's current romantic partner. With an increasing number of LGBTIQ-parented families, more detailed research on their reasons for and against parenthood is necessary.

\subsection{Parenthood motivation among LGBTIQ people}

Based on a national sample from the United States, the Pew Research survey (2013) showed that while in the general public almost all adults either already had children or wanted to have them, among LGBT adults only about a quarter $(28 \%)$ of those who were not already parents reported they would like to have children, $34 \%$ were not sure, and $36 \%$ did not want to have children. When it comes to the cultural contexts more similar to Croatia, a Slovenian study on the everyday life of gays and lesbians showed that $40 \%$ of the respondents wanted to have a child, $38 \%$ did not want to, and $17 \%$ did not know (Švab and Kuhar, 2005). Differences in parenting desire between homosexual and heterosexual people were also found in the research where heterosexual participants were matched with their lesbian or gay peers at the gender, race/ethnicity, and education level (Riskind and Patterson, 2010; Baiocco and Laghi, 2013). However, despite a less frequent parenting desire, gays and lesbians endorsed the value of parenthood just as strongly as the heterosexual participants (Riskind and Patterson, 2010).

LGBTIQ people do not only face many obstacles and prejudices on their pathway to parenthood but also often do not even consider parenting due to the existing barriers. For example, in a Belgian study on lesbian couples who applied for donor insemination, $17 \%$ of prospective biological mothers and $12 \%$ of their partners (future non-biological mothers) reported not considering parenthood for some time in their lives because of their sexual orientation (Beatens, Camus and Devroey, 2002). Before making a final decision, most couples discussed their wish for a long time focussing on all the possible consequences for a child raised by two women. A Slovenian study also showed that lesbians and gays supressed their thoughts 
about children due to realistically small chances to become parents (legal barriers) and the guilt arising from feeling parenting desires in a homophobic context (Švab and Kuhar, 2005). In addition, the participants from that Slovenian study stressed the internalised homophobic attitudes that they, as gays and lesbians, did not have the right to become parents. Finally, the research from the Netherlands showed that, although in the Dutch context same-sex couples have more rights regarding parenthood in comparison to some post-socialist European countries like Slovenia or Croatia, lesbian couples were more engaged in parenthood planning and thought about their motives more than heterosexual couples (Bos, van Balen and van den Boom, 2003).

In Goldberg, Downing and Moyer's (2012) qualitative study, 35 pre-adoptive gay male couples expressed a range of psychologically-oriented reasons shaping their decision to become parents. The participants were motivated by seeing parenthood as psychologically or personally fulfilling, which included valuing family ties, a sense that raising children is a natural part of life, the desire to give the child a good home, and the desire to teach their child tolerance. Nine men reported that their partner's strong desire to become a parent was the primary motivation for parenthood. Only four men mentioned they wanted to have children because they did not want to be alone in old age. In Larsen's (2011) study twelve gay male couples were interviewed during their pursuit of parenthood. They reported memories of the desire to become a father from a very young age and they had long discussed those desires with their partner, families, and friends. Some couples identified the value of establishing a legacy, while others desired to have children so they would have a family to spend time with while they grew older. Other participants expressed that becoming a father was a natural next step in the evolution of their relationship. Based on the narratives of parental desire and decision-making from the ethnographic research on gay male intimacy, Stacey (2006), identified the described reasons as one end of the passion-for-parenthood continuum and named it "predestined parents". On the opposite end of the continuum, the author identified "parental refuseniks" characterised by no appeal for parenthood or even by interpreting freedom from parenthood as a compensatory reward for being gay.

In a qualitative study with nine lesbian couples in Great Britain who were expecting a child or already had (a) child(ren) with their current partner, internal and external factors in making a decision about having children emerged (Touroni and Coyle, 2002). Regarding the internal factors, the participants emphasised a lifelong and consistent wish to become parents and the feeling that they had reached a stage in their lives and relationships where it was appropriate to have children. Regarding the external factors, the participants reported the impact of the social context and changes which opened up the possibility for lesbian parenthood. 
Studies including transgender individuals have shown that they are also motivated to become parents, but specific determinants of their motivation have not yet been researched. In an Australian study by Riggs, Power and von Doussa (2016) on 160 trans or gender diverse people, $24 \%$ of the participants already had children. Among the participants who were not parents, $18 \%$ desired to have children in the future, $53 \%$ did not want to have children, and $29 \%$ were unsure.

As this brief overview shows, the research on the determinants of parenthood motivation has been mainly qualitative and focussed on the individuals who want to become parents, while the experiences of those who want to remain childfree were mostly neglected. The described reasons can be roughly grouped into internal, i.e. relating to personal and psychological factors, and external, i.e. situational, cultural, and social. Goldberg et al. (2012) concluded that since the desire to parent is human, neither heterosexual nor homosexual, we would expect the internal reasons for parenthood to be dominant along with the external reasons against parenthood due to existing legal and social barriers for LGBTIQ people.

\subsection{Present study}

The issue of parenthood among LGBTIQ people is highly intertwined with the legal and social contexts. Most of the aforementioned studies were conducted in Western(ised) cultures that are on the one hand diverse but on the other hand similar in a rather high level of protection of human and family rights for LGBTIQ people (Lubbe, 2012). In Europe, it is not uncommon for some geographically close countries to have very different legal frameworks when it comes to LGBTIQ-parented families. For example, in Germany, Spain or Denmark, same-sex partners can get married and adopt children, while in Slovenia, Montenegro, and Croatia their partnership is recognised through special laws but there is no possibility for them to adopt, or use assisted reproductive technology to become parents. Finally, in countries like Bosnia and Herzegovina, same-sex partners are not recognised at all in legal documents.

Beyond doubt, the institutional, political, legal and social frameworks have a substantial impact on LGBTIQ-parented families because, as Lubbe (2012) argues, before LGBTIQ people can become more open and dare to venture into parenthood, the basic human need of being secure must be fulfilled. In Croatia, legal barriers exist along with a rather homophobic climate (European Union Agency for Fundamental Rights, 2014; Jugović, Pikić and Bokan, 2007), ${ }^{4}$ but despite limited

4 Detailed description of legal framework in Croatia is described in Štambuk et al. (2019) and Štrbić et al. (2019) from this issue. 
possibilities, there is a significant interest in parenthood among LGBTIQ people. Non-heterosexual and non-cisgender parents already exist, as well as a growing number of LGBTIQ people who express a strong desire for parenthood, consider different possibilities, and see parenthood as a crucial part of their life plans.

A recent study showed that $39 \%$ of LGBTIQ participants intended to have children, $23 \%$ did not, and $38 \%$ were not yet sure (Milković, 2013). In the same study, $5 \%$ of participants already had children. In the only previous study including LGB parents and their children in Croatia (Maričić et al., 2016), the parents reported a dominantly intrinsic motivation for parenthood. Specifically, they talked about the desire to care for children, happiness and personal fulfilment as well as the importance of the attachment between them and children. Similarly, the results of the same study, obtained from a focus group with LGB people planning parenthood, showed that they perceived the desire for parenthood as an intrinsic personal wish occurring naturally. As only parents and individuals planning parenthood participated in that study, the reasons why LGB people do not want to become parents were not researched.

The main goal of the present study was to explore reasons to become a parent or remain childfree among LGBTIQ people in Croatia. The first aim was to assess how many participants wanted to, were not sure, or did not want to become parents. Due to restricted legal possibilities and a rather homophobic social context, as well as in line with the previous study on LGBTIQ participants in Croatia, we expected that the proportion of the participants who want to have children would be lower than typically found in heterosexual people. The second aim was to identify the main reasons for and against parenthood and to test the differences in those reasons between the participants who want, are not sure, and who do not want to become parents. In line with previous studies that lead to the conclusion about the parenting desire as innate and inherently human, we expected that the internal reasons for parenthood would be most stressed by the participants who want to have children and the internal reasons against parenthood among those who do not want to have children. Considering that LGBTIQ people must deal with a negative public opinion and legal barriers regarding their parenthood, the third aim was to generate additional reasons for or against parenthood. We expected that some of the additional reasons would be general, especially among the reasons for parenthood but also that some more society-specific reasons would emerge, especially among the reasons against parenthood. 


\section{METHOD}

\subsection{Participants and procedure}

The online survey study included 558 participants, of which 72 did not meet the inclusion criteria for this paper. The excluded participants either did not self-identify as LGBTIQ $(n=9)$, were Croatian citizens living abroad $(n=26)$, already had children $(n=24)$, or were under the age of $18(n=13)$. In the final sample $(N=486)$, participants' average age was 28 years and 3 months $(S D=7.12)$ ranging from 18 to 54 years.

Most participants reported high school $(40 \%)$ or college $(30 \%)$ as the highest completed educational level. Roughly a third of the participants were students $(37 \%)$ while half of them were employed $(52 \%)$, either full-time or as freelancers. Most of the participants (62\%) lived in a larger city (>500 000 residents) and considered their life standard to be average $(44 \%)$ or above average $(29 \%)$. Half of the participants $(51 \%)$ reported that they were in a relationship lasting from one month to 21.5 years $(M=3.30, S D=3.29)$. About half of the participants $(55 \%)$ reported their sex identity as female and gender identity as woman, while a third (34\%) reported their sex identity as male and gender identity as a man. The participants reported their sexual orientation as homosexual $(65 \%)$, bisexual (22\%), pansexual $(3 \%)$, heterosexual $(1 \%)$, and asexual $(<1 \%)$, while $6 \%$ did not identify their sexual orientation and additional $1 \%$ labelled it as "other". ${ }^{5}$

The survey was conducted online, lasting for 6 months (the summer and autumn of 2016) and using the Google Forms tool with snowball sampling. We reached out to participants through relevant web sites, social networks, non-governmental organisations, and mental health experts working with LGBTIQ people. The participants were invited to share the survey link further. Prior to participation, the participants were provided with a form of informed consent and agreed to participate in the study anonymously and voluntarily.

\subsection{Measures}

The socio-demographic measures included age, education level, working status, life standard, county of residence, relationship status and length, sexual orientation, sex, and gender identity.

5 For further details on participants' sexual orientation, sex, and gender identities see Štambuk et al. (2019) from this issue. 
The parenting desire was indicated by six response options that were a combination of reports on whether the participant was already a parent ("I am a parent and..." / "I am not a parent and...") with three levels of desire ("I do not want..." / "I do not know if I want..." / "I want to have children in the future").

Two scales measuring reasons for and against parenthood (Langdridge et al., 2005) were translated to Croatian using back-translation with the author's permission. The Reasons for Parenthood (RFP) consists of 20 items beginning with "I want to have a child because...") followed by a reason (e.g. "I want to give love and affection to a child"). The Reasons against Parenthood (RAP) has a similar layout, with 15 items beginning with "I do not want to have a child because..." followed by a reason (e.g. "I do not want the responsibility of bringing up a child"). The participants reported to what extent every reason influences them to (not) want a child on a 5-point scale ranging from 1 ("Does not influence") to 5 ("Very strongly influences"). A principal component exploratory factor analysis was performed using Oblimin rotation with Kaiser normalisation, separately for the RFP and RAP scales. In both analyses, the number of factors was determined using the Guttman-Kaiser criterion and Cattell's scree test. For the RFP a 3-factor solution emerged. The first factor covered the internal reasons relating to positive aspects of having children and the parent-child relationship (IRF; $\lambda=8.52 ; 43 \%$ variance explained). The second factor described the external reasons related to the expectations from family, tradition, and religion (ERF; $\lambda=2.08 ; 10 \%$ variance explained). The third factor included reasons involving the effects of having a child on partnership (PRF; $\lambda=$ 1,$35 ; 7 \%$ variance explained). The analysis of the RAP resulted in a 2 -factor solution. The first factor covered internal reasons reflecting expectations and personal limitations relating to having children (IRA; $\lambda=6.87 ; 46 \%$ variance explained). The second factor described the external reasons related to difficulties that having a child could cause for one's finances, career, and partnership (ERA; $\lambda=1.53 ; 10 \%$ variance explained). Cronbach's a coefficient indicated acceptable to excellent internal consistency for both the RFP $\left(\alpha_{\mathrm{IRF}}=.93 ; \alpha_{\mathrm{ERF}}=.74 ; \alpha_{\mathrm{PRF}}=.85\right)$ and RAP subscales $\left(\alpha_{\text {IRA }}=.92 ; \alpha_{\text {ERA }}=.77\right)$. None of the items lowered the internal consistency of the corresponding subscales. Total scale result was calculated as a mean score for each RFP and RAP subscale separately with higher results indicating a greater influence of the corresponding category of reasons.

Additional reasons for and against parenthood were explored in the qualitative section of the questionnaire. To our knowledge, Langdridge and colleagues' (2005) scale was used only on heterosexual individuals. ${ }^{6}$ Considering the challenges that

$6 \quad$ There does not appear to be an existing scale encompassing specific reasons why people in general, as well as socially marginalised groups, want or do not want to have children. Using the same scale for all participants regardless of their sexual orientation allows for the empirical testing 
LGBTIQ people face regarding parenthood, we expected that the original scales would not sufficiently cover all the relevant reasons why they wanted and, especially, did not want to become parents. Accordingly, using two open-ended questions we asked the participants to describe if they had additional reasons that influenced their desire to want or not to want children.

\subsection{Analytical Strategy}

The results are presented in two sections. First, we presented quantitative data. Using descriptive statistics (percentages) we reported how many participants wanted, did not want, and did not know if they wanted to have children. In order to test differences between the groups of participants based on their parenting desire on different reasons categories, as well as to identify which reason category is the most important in participant groups based on parenting desire, we used a mix model analysis of variance (ANOVA) and a subsequent repeated measures analysis or paired t-test separately for the reasons for and reasons against parenthood. To analyse the reasons for and against parenthood in more detail, we reported descriptive statistics (means and standard deviations) for each reason and performed a series of multivariate analyses of variance (MANOVAs) separately for each RFP and RAP subscale to test the differences in each reason between participant groups. In the second section, we presented qualitative data about additional reasons for and against parenthood.

\section{RESULTS}

\subsection{Reasons for and against parenthood}

Almost half of the participants reported they want to have children in the future (46\%), roughly a third do not know (35\%), and approximately one fifth do not want to have children (19\%).

Regarding the reasons for parenthood (Figure 1), the results of the mix model ANOVA showed a statistically significant main effect of the within-subjects factor - reasons for category $\left(F(1.97,951.93)=491.75, p<.001 ; \eta^{2}=.50\right)$ and the between-subjects factor - the group based on participants' parenting desire $(F(2$,

of stereotypes. Our study did not include direct comparison, but we could compare the results collected on the same scale in different populations to interpret and argue our findings. Also, we find it very important that we could compare our results to those found in Croatia among a general population of participants in emerging adulthood (18 to 30 years of age; Hanzec Marković and Štambuk, 2019). 
$\left.483)=176.37, p<.001 ; \eta^{2}=.42\right)$. The interaction of the group by reasons category was also significant $\left(F(3.94,951.93)=39.25, p<.001 ; \eta^{2}=.14\right)$. The results of the subsequent repeated measures analysis on groups based on participants' parenting desire showed that in the want $\left(\eta^{2}=.69\right)$ and do not know groups $\left(\eta^{2}=.56\right)$ participants rated internal reasons for parenthood as the most influential, followed by reasons related to partnership, and external reasons as the least influential. In the do not want group, differences were also significant $\left(\eta^{2}=.31\right)$, but here external and partnership reasons were equally rated and less influential than internal ones. However, in this group, all categories of reasons on average only slightly influenced the participants to want a child.

Figure 1. Differences in results on the Reasons for Parenthood subscales within participants and between groups

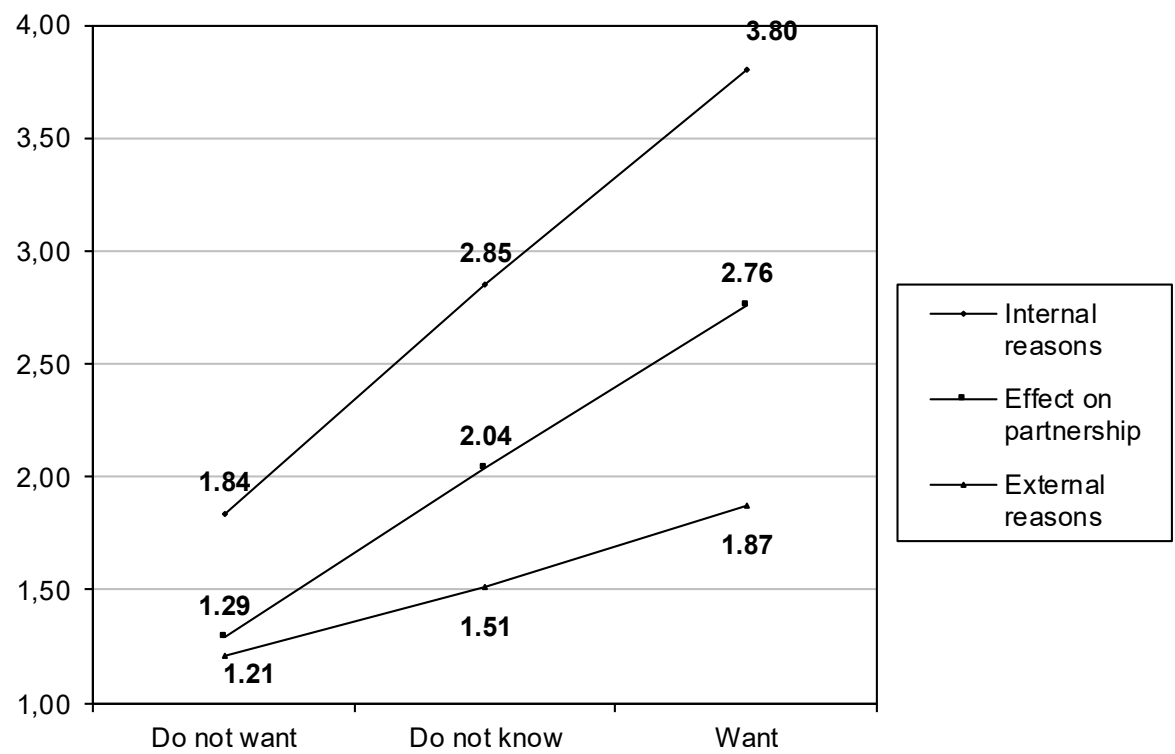

Regarding the reasons against parenthood (Figure 2), the results of the mix model ANOVA showed a significant main effect of the within-subjects factor - reasons against category $\left(F(1,483)=111.44, p<.001 ; \eta^{2}=.19\right)$, between-subjects factor - group based on participants' parenting desire $\left(F(2,483)=116.33, p<.001 ; \eta^{2}=\right.$ $.33)$, and interaction of the group by reasons category $(F(2,483)=99.47, p<.001$; $\left.\eta^{2}=.29\right)$. The results of the subsequent paired samples t-test on groups based on the participants' parenting desire showed that internal reasons were rated as more influential than external in the do not want $(r=.63)$ and do not know groups $(r=$ 
.55). Conversely, in the want group, internal reasons were rated as less influential than external ones $(r=.68)$. However, participants in the want group reported that on average, both categories of reasons have a very low influence on them.

Figure 2. Differences in results on the Reasons against Parenthood subscales within participants and between groups

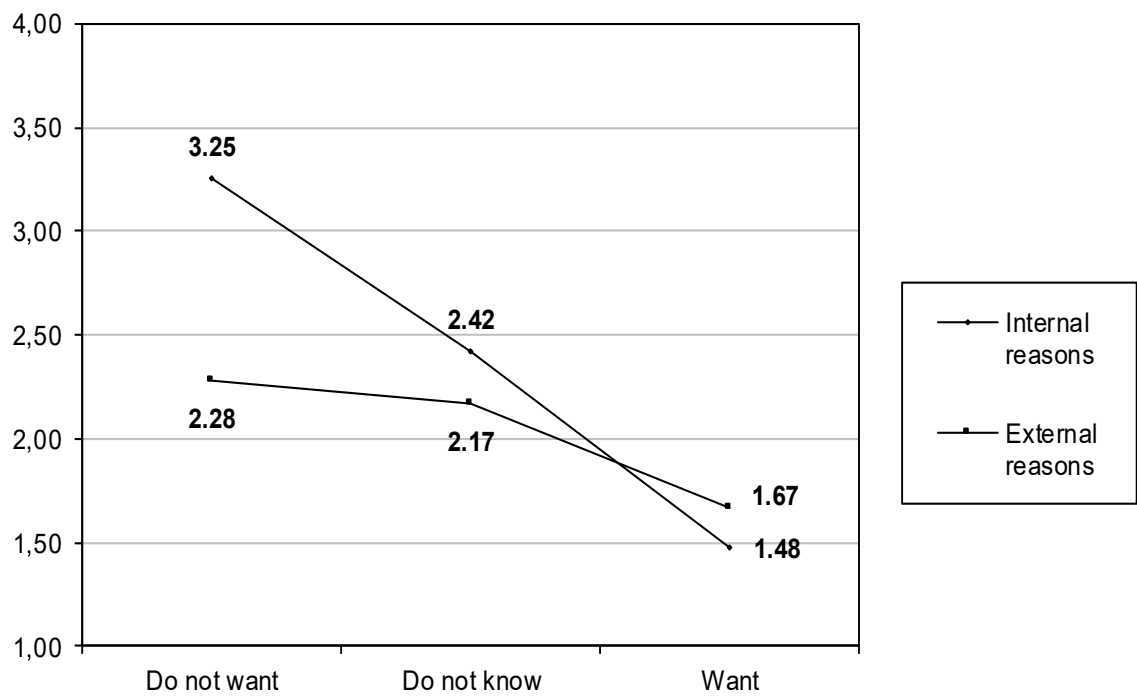

The comparisons of participant groups concerning different categories of reasons for and against parenthood indicated that the participants' desire for as well as against parenthood was mostly shaped by internal reasons. Further analysis (Table 1) showed that the most important internal reasons for parenthood among the participants who want to have children are the desire to give love, share knowledge, and develop a special bond with a child. Among the internal reasons against parenthood, the participants who do not want children are mostly concerned with restricted freedom, high responsibility, and a lot of work as part of parenthood. To test the differences in each reason between participants' groups we performed a series of MANOVA analyses separately for each RFP and RAP subscale. The differences were significant for all reasons except one - the risk of having a disabled child. 
Table 1. Differences in reasons for and against parenthood between participants based on their desire to have children

\begin{tabular}{|c|c|c|c|c|c|c|c|}
\hline & \multicolumn{2}{|c|}{ Do not want } & \multicolumn{2}{|c|}{ Do not know } & \multicolumn{2}{|c|}{ Want } & \multirow{2}{*}{$\eta^{2}$} \\
\hline & $M$ & $S D$ & $M$ & $S D$ & $M$ & $S D$ & \\
\hline \multicolumn{8}{|c|}{$\begin{array}{l}\text { Reasons for parenthood } \\
\text { Internal reasons } \\
\left(F(20,948)=20.37, p<.001, \eta^{2}=.30\right)\end{array}$} \\
\hline Give love & 2.33 & 1.46 & 3.55 & 1.27 & 4.56 & 0.77 & .36 \\
\hline Share knowledge & 2.46 & 1.47 & 3.75 & 1.23 & 4.48 & 0.87 & .30 \\
\hline Bond with child & 1.67 & 1.10 & 2.96 & 1.30 & 4.19 & 1.07 & .40 \\
\hline Fulfilment & 1.59 & 1.04 & 2.81 & 1.27 & 4.02 & 1.10 & .39 \\
\hline Good home & 2.51 & 1.50 & 3.20 & 1.24 & 3.92 & 1.03 & .17 \\
\hline Receive love & 1.78 & 1.07 & 2.80 & 1.25 & 3.81 & 1.19 & .30 \\
\hline $\begin{array}{l}\text { Shape new } \\
\text { generation }\end{array}$ & 2.05 & 1.33 & 2.96 & 1.36 & 3.70 & 1.32 & .18 \\
\hline Strive for children & 1.30 & 0.66 & 2.10 & 1.11 & 3.20 & 1.34 & .29 \\
\hline Fun & 1.42 & 0.76 & 2.36 & 1.26 & 3.11 & 1.31 & .22 \\
\hline Invest in future & 1.31 & 0.84 & 2.08 & 1.08 & 2.96 & 1.38 & .22 \\
\hline \multicolumn{8}{|c|}{$\begin{array}{l}\text { Effect on partnership } \\
\left(\mathrm{F}(8,960)=25.47, \mathrm{p}<.001, \eta^{2}=.18\right)\end{array}$} \\
\hline $\begin{array}{l}\text { Child as a part of } \\
\text { both of us }\end{array}$ & 1.47 & 1.01 & 2.36 & 1.27 & 3.28 & 1.37 & .23 \\
\hline Make family & 1.13 & 0.43 & 1.96 & 1.12 & 3.02 & 1.41 & .28 \\
\hline Please partner & 1.42 & 0.82 & 2.14 & 1.18 & 2.66 & 1.35 & .13 \\
\hline $\begin{array}{l}\text { Good for } \\
\text { relationship }\end{array}$ & 1.18 & 0.44 & 1.69 & 0.91 & 2.09 & 1.20 & .11 \\
\hline \multicolumn{8}{|c|}{$\begin{array}{l}\text { External reasons } \\
\left(F(12,956)=12.06, p<.001, \eta^{2}=.13\right)\end{array}$} \\
\hline Biological drive & 1.10 & 0.40 & 1.67 & 0.92 & 2.56 & 1.31 & .23 \\
\hline $\begin{array}{l}\text { Care in the old } \\
\text { age }\end{array}$ & 1.55 & 0.93 & 1.88 & 1.06 & 2.16 & 1.21 & .04 \\
\hline Please family & 1.34 & 0.81 & 1.68 & 0.94 & 2.00 & 1.18 & .05 \\
\hline Family name & 1.25 & 0.69 & 1.62 & 1.00 & 1.94 & 1.17 & .06 \\
\hline $\begin{array}{l}\text { Most people want } \\
\text { one }\end{array}$ & 1.02 & 0.15 & 1.18 & 0.50 & 1.39 & 0.78 & .06 \\
\hline Religion & 1.00 & 0.00 & 1.04 & 0.20 & 1.16 & 0.61 & .02 \\
\hline
\end{tabular}




\begin{tabular}{|c|c|c|c|c|c|c|c|}
\hline & \multicolumn{2}{|c|}{ Do not want } & \multicolumn{2}{|c|}{ Do not know } & \multicolumn{2}{|c|}{ Want } & \multirow{2}{*}{$\eta^{2}$} \\
\hline & $M$ & $S D$ & $M$ & $S D$ & $M$ & $S D$ & \\
\hline \multicolumn{8}{|c|}{$\begin{array}{l}\text { Reasons against parenthood } \\
\text { Internal reasons } \\
\left(F(16,952)=24.88, p<.001, \eta^{2}=.30\right)\end{array}$} \\
\hline Restrict freedom & 4.00 & 1.21 & 3.36 & 1.31 & 1.96 & 1.05 & .34 \\
\hline Responsibility & 3.70 & 1.44 & 2.67 & 1.32 & 1.52 & 0.82 & .35 \\
\hline A lot of work & 3.60 & 1.30 & 2.76 & 1.26 & 1.63 & 0.89 & .33 \\
\hline Other things & 3.25 & 1.55 & 2.11 & 1.15 & 1.28 & 0.61 & .33 \\
\hline Lack of patience & 3.22 & 1.44 & 2.25 & 1.25 & 1.38 & 0.72 & .29 \\
\hline Emotional strain & 3.00 & 1.54 & 2.35 & 1.32 & 1.48 & 0.84 & .21 \\
\hline $\begin{array}{l}\text { Do not like } \\
\text { children }\end{array}$ & 2.68 & 1.53 & 1.64 & 1.02 & 1.13 & 0.50 & .26 \\
\hline $\begin{array}{l}\text { Would not be a } \\
\text { good parent }\end{array}$ & 2.63 & 1.53 & 2.21 & 1.30 & 1.46 & 0.80 & .14 \\
\hline \multicolumn{8}{|c|}{$\begin{array}{l}\text { External reasons } \\
\left(\mathrm{F}(14,954)=9.71, \mathrm{p}<.001, \mathrm{\eta}^{2}=.13\right)\end{array}$} \\
\hline Financial issues & 2.88 & 1.50 & 2.69 & 1.33 & 1.92 & 1.07 & .10 \\
\hline $\begin{array}{l}\text { Less time with } \\
\text { partner }\end{array}$ & 2.64 & 1.56 & 2.24 & 1.23 & 1.58 & 0.90 & .11 \\
\hline $\begin{array}{l}\text { Interferes with } \\
\text { career }\end{array}$ & 2.49 & 1.49 & 2.48 & 1.35 & 1.72 & 0.97 & .09 \\
\hline Over-population & 2.35 & 1.57 & 1.88 & 1.25 & 1.33 & 0.82 & .10 \\
\hline Disabled child & 2.13 & 1.38 & 2.11 & 1.22 & 2.04 & 1.24 & n. sig. \\
\hline $\begin{array}{l}\text { Cause strain for } \\
\text { the couple }\end{array}$ & 1.76 & 1.21 & 1.75 & 1.01 & 1.36 & 0.73 & .04 \\
\hline Partner's wishes & 1.70 & 1.14 & 2.02 & 1.14 & 1.76 & 1.04 & .02 \\
\hline
\end{tabular}

\subsection{Reasons for and against parenthood: Qualitative data}

Additional reasons for and against parenthood were analysed using thematic analysis (Braun and Clarke, 2006). Key themes were formulated as suggestions for new items in future research and illustrated with primary data in Tables 2 and $3 .^{7}$ Overall, 96 participants (20\%) described additional reasons that encouraged their desire to have children and $110(23 \%)$ gave reasons why they did not want to have children.

$7 \quad$ Items in Croatian are available on request. 
Table 2. Additional reasons for parenthood indicated by participants

Item formulation

I want to have a child because...

...I believe I would be a good parent.

...I believe that my partner and I would be good parents.

...I have financial and emotional resources to have a child.

...I want to give him/her what I have not received from my parents.

...I want to teach him/her empathy, solidarity, and tolerance.

...I want to adopt or foster a child in need.

...I see parenthood as an ultimate life goal and a way of self-actualisation.

...I feel a maternal/parental urge.

...I like children.

...I would regret not having a child.

\section{Examples of primary data}

I think I would be a good mother.

We could be great parents and I know we would give all to our child.

I have financial resources, time, mental and emotional capacity to have a child. I do not see as a problem taking care for a child at the age of 27 with a stable job, decent pay, and my own roof over my head (and grandma service at hand).

I think that my lifestyle (active life - recreation and being in nature, emotional responsibility, higher education, open communication, openness to diversity ...) is a significant shift from the environment I grew up in - I would break the vicious cycle of abusive relationships in the family I'm coming from.

We want to raise a child according to the values that are very important to us, which we think are underrepresented and positive (compassion, empathy, solidarity, openness, freedom).

I prefer the idea of adopting a child in need rather than having my own (biological) offspring, I consider adopting a noble act.

My view is that having children is the only way for individuals to actualise themselves as human beings in the full sense of these words.

It's so hard to describe that feeling I have, but it's kind of natural to me, my inner wish.

Children have wonderful energy, it fills you up to heaven and back, they listen and hear, they feel.

Since l've been working with small children, I realised how much I like "to be a child" together with them. They bring me some particular peace and energy.

I'm afraid I would regret the decision not to have them, and at one point it could be too late to become a parent. 
Table 3. Additional reasons against parenthood indicated by participants

Item formulation

I do not want to have a child because...

.... am worried about political and climate changes.

...I am afraid of the discrimination that my child could experience.

...I am afraid of negative reactions from my family.

...the legal system does not provide same-sex couples with a possibility to become parents.

...I do not feel the urge to become a parent.

...I feel a social pressure that as an LGBTIQ person I should not become a parent.

...I am not yet ready for having children.

...I am afraid of pregnancy and delivery.

\section{Examples of primary data}

I'm afraid where this world is going: pollution, restrictions of freedom, etc.

I fear for a child, the world that we would bring it in generally is not the most beautiful place possible.

The child would be born with an additional "burden" of having two mothers. I am afraid that our love and encouragement would not be enough for him/her to cope with bullying because his/her mummy is a lesbian. [...] The biggest reason why I have doubts about having a baby in this environment where we live, is that this environment is so cruel to children who come from normative families, let alone those who are different.

I don't want my child to fight my battles, I don't want $\mathrm{him} / \mathrm{her}$ to suffer in any way because of my choices and decisions.

I am afraid of reactions from my own family as they do not accept the fact that I am in a relationship with a same-sex person.

Becoming a parent means overcoming the law and investing considerable financial resources in trying to become a parent abroad.

I just do not feel that urge, neither does my partner.

I have a feeling that I have never honestly wondered whether I wanted it or not. [...] Is it because of me or society? I just know that in the past, when I realised that I was gay, I thought "gay equals you can't have kids". [...] And now I wonder if this is something I just swallowed without chewing, if it is really true, or is something I subconsciously accepted from the environment.

It seems that I haven't found my own identity yet and that having a child would make me even more lost.

Fear of childbirth, especially in the society we live in, where a pregnant woman experiences a lot of violence. 


\section{Item formulation}

I do not want to have a child because...

...of my health issues.

\section{Examples of primary data}

My health condition would make it difficult to care for a child as much as s/he needs and deserves.

If it is a biological child; I fear that s/he would inherit my autoimmune (chronic) illness.

Mature life age. child.

\section{DISCUSSION}

This study provides new insights into the parenthood motivation among LGBTIQ people, a research field which is growing rapidly internationally but is understudied in non-Western contexts such as Croatia. Our results showed that almost half of the participants want to have children and their main reasons for parenthood are internal. Similarly, the participants who do not want to have children mostly stress the internal reasons against parenthood. Additional reasons for and against parenthood emerged from the qualitative data. Those reasons reflected themes universal for all people regardless of sexual orientation or gender identity as well as concerns about specific societal and legal barriers LGBTIQ people face concerning parenthood.

\subsection{Parenting desires}

Due to a lack of research on this topic in Croatia, we can only compare our results on parenting desires with previous results on parenting intentions. The findings from a study on a Croatian sample of LGBTIQ people (Milković, 2013) showed that $39 \%$ of the participants intended to have children while in our research $46 \%$ desire to do so. This difference may be reflecting a rising trend in parenthood aspirations after the implementation of the Same-Sex Life Partnership Act in 2014. However, this difference could also reflect differences in the meaning and consequences of desires and intentions. According to Freitas and Testa (2017), parenting desires lead to parenting intentions and intentions are more predictive of reproductive behaviour. Thus, it is expected that more people express a desire for parenthood rather than intention. 
When comparing our results to parenthood desire in a Croatian sample of general public emerging adults (Hanzec Marković and Štambuk, 2019), LGBTIQ participants were far less likely to want to have children: $46 \%$ in comparison to $86 \%$. A similar difference was consistently found in other countries (Baiocco and Laghi, 2013; Riskind and Patterson, 2010). Discriminative legal barriers that prevent same-sex couples from becoming parents are still strong in Croatia and many other countries in Europe. Entering into a life partnership, recognised by the Croatian parliament, means that same-sex couples cannot adopt or foster a child nor access assisted reproductive technologies in Croatia. At the same time, non-registered same-sex couples and single LGBTIQ people are protected by the Anti-Discrimination Act (2008), so they can apply for adoption or foster care, but to use assisted reproduction technologies they would have to provide medical information on prolonged infertility. Besides that, the prevailing public attitude is that parenthood is only appropriate for married heterosexual couples (Huić, Jugović and Kamenov, 2015; Kamenov, Huić and Jelić, 2019). These circumstances probably influence many LGBTIQ people not to even consider parenthood. For them, being LGBTIQ is equivalent to staying childless (Beatens et al., 2002; Švab and Kuhar, 2005). For example, after coming out as gay, many men recognised their parenting desires and at the same time became aware of many barriers to becoming a parent (Berkowitz and Marsiglio, 2007). It is also worth mentioning that heterosexual men and women who are "childless by circumstances" showed elevated levels of depressive symptoms compared to those who are "childfree by choice" (Connidis and McMullin, 2002). Having that in mind, unfulfilled parenting desires may be a risk factor for depression among LGBTIQ people who want children.

\subsection{Reasons for and against parenthood}

In line with a UK study on married heterosexual couples (Langdridge et al., 2005), our participants reported their motivation for and against parenthood primarily in terms of internal reasons and less as external pressures. According to Thornton and Young-DeMarco's (2001) review of parenthood attitudes, a significant reduction in the degree of external reasons influencing parenthood motivation happened already during the 1960s and 1970s. In other words, people started explaining their motivation for parenthood more frequently in terms of personal well-being, satisfaction, and happiness. Stacey (2006) sees the contemporary pursuit of parenthood as a shift from obligation to desire, and from economic to emotional calculation. Adults who want children nowadays mostly do not expect any material advantage or social security, but primarily seek intimate bonds with children. 
The present study shows moderate importance of reasons related to the effects of having a child on partnership for those who want and who are not sure if they want children. Previous research corroborates our findings that these are relevant motives for wanting a child. For example, heterosexual individuals, particularly men, frequently describe their motivation for parenthood as driven, at least in part, by their partner's desire (Miller and Pasta, 1996). Similarly, in a qualitative study including pre-adoptive gay male couples (Goldberg et al., 2012) participants reported that their partner's strong desire to become a parent was the primary motivation for parenthood. Some heterosexual men and women (Newton et al., 1992), as well as lesbian (Touroni and Coyle, 2002) and gay couples (Larsen, 2011), see having children as something that will "complete" their marriage or as the next logical step in the relationship.

This study shows that the most important specific reasons for LGBTIQ people who want to have children are the desire to give love, share knowledge, and develop a special bond with a child. Those who do not want children are mostly concerned with restricted freedom, high responsibility, and a lot of work as part of parenthood. These findings are similar to those found among heterosexual people in Croatia (Hanzec Marković and Štambuk, 2019), Sweden (Thompson and Lee, 2011), and the United Kingdom (Langdridge, et al., 2000). Moreover, comparisons among LGBTIQ individuals who want, do not want and do not know if they want children showed the same results as in Langdridge and colleagues' (2005) study. The differences were significant for all but one reason - the concern about having a disabled child.

Langdridge and colleagues' (2005) scales for and against parenthood have been constructed and used only among heterosexual people. Thus, it was reasonable to assume that important reasons specific for LGBTIQ population could be missing from this scale. Additional reasons that positively influenced their desire to have a child were reported by $19 \%$ of our participants, while slightly more, $22 \%$ of the participants, offered additional reasons for not wanting children. Almost all of the additional reasons for parenthood are quite general and can represent motives of any population (cf. Table 2). Those reasons were mainly recognised in the literature earlier (Lampic et al., 2006; Tydén et al., 2006). However, additional reasons such as motivation to teach children empathy, solidarity, and tolerance, or to give the children what participants have not received from their parents, seems more representative of LGBTIQ people, as well as members of other oppressed minority groups.

Expectedly, more issues specific for LGBTIQ people emerged among the reasons against parenthood. Two groups of fears and restrictions are noticeable: those concerning the social treatment of the child (e.g. possible discrimination, 
negative reactions from the family) and personal restrictions (e.g. social pressure to stay childless, legal barriers to parenthood). These fears and reasons against parenthood were earlier recognised in a similar socio-political context (Švab and Kuhar, 2005). The analysed statements of gays and lesbians in the Slovenian research showed that anxiety may even lead to the experience of guilt and denial of the right to parenthood. Some participants described that they suppress their parenting thoughts because of the fear that any serious consideration of parenting their own child would be too burdensome given the slim chance. By not confronting fear and anxiety, gays and lesbians subtly reinforced the heteronormative ideas that same-sex parenthood is both legally impossible and socially unacceptable.

Finally, other more general reasons that were added by the participants, such as political and climate changes or the fear of pregnancy and delivery, seem to be a valuable contribution to the list of reasons against parenthood for the general population as well.

\subsection{Limitations and future research}

Several limitations apply to the present study and can be useful guidelines for future research. First, the results may be limited due to the online methodology, with no in-built duplicate protection, ${ }^{8}$ and snowball (non-probabilistic) sampling. Our participants had a higher education and economic status than the average. Also, they were mostly young adults and lived in big urban areas. Since these characteristics are relevant to parenting desires, intentions, and behaviours (e.g. Weston et al., 2004) future studies should include a larger and more diverse sample to appropriately cover the experiences among different LGBTIQ people. A second methodological problem concerns the use of self-report measures. It is possible that, consciously or unconsciously, our participants were somewhat affected by the social desirability response bias. However, our results show a range of experiences and are corroborated with previous findings as well as qualitative data. Third, legal barriers reflect differently on LGBTIQ people's possibilities for achieving parenthood and the social perception of them also varies. Thus, one promising venue for future studies is the comparison of the relevance of different reasons to

8 The Google Forms tool used in this study has no in-built duplicate protection, so we were not able to use either IP-based or Cookie-based duplicate protection. However, it is important to note that neither of the existing duplicate protections is highly efficient, and both have serious shortcomings. IP-based duplicate protection would not be an option because some environments share a single IP address (corporations, universities, hospitals, dormitories etc.). Cookie-based duplicate protection would be more appropriate, but cookies are set on a specific browser and a specific device, and if a participant accessed the survey from more than one device or browser, they would not be permitted to enter. 
LGBTIQ people depending on their sexual identity. Finally, in the qualitative part of the study, we offered some additional items concerning reasons for and against parenthood that need to be tested empirically in terms of psychometric properties and predictive value in future research.

\section{CONCLUSION AND IMPLICATIONS}

The development of this research field and dissemination of findings are crucial for the development of evidence-based policies that can support and protect different types of families (e.g. Van Eeden-Moorefield et al., 2018). In trying to give empirical support for achieving this goal in Croatian society, this study examined reasons for and against parenthood on a sample of LGBTIQ people. Contrary to prevalent stereotypes, the results showed that a substantial portion of participants want to become parents. However, around half of them do not know or do not want to have children. We argue that the common belief that LGBTIQ people should not or cannot be parents, as well as legal obstacles and psychological barriers, may undermine the recognition or development of their parenthood desire.

People that want children are influenced mainly by internal motives for parenthood, and people that do not want children mostly stress internal reasons against parenthood. Expectedly, only people that do not know if they want children find both groups of reasons relevant. LGBTIQ participants in the present research seem to rank their parenthood motives similarly to heterosexual people, and internal reasons as more important than external. In other words, the results of our study add to the conclusion that the desire to parent is human, neither heterosexual nor homosexual (Goldberg et al., 2012). However, there are specific motives and fears that LGBTIQ people face regarding parenthood.

Having the results of our study in mind, it should not be assumed, especially among policymakers and health workers, that LGBTIQ people are uninterested in parenthood. Moreover, they should get acquainted with the specifics of LGBTIQ people's perspective, especially with the psychosocial odds that may not work in their favour. Most notable among them seem to be the obstacles presented by society and LGBTIQ people's own families. 


\section{REFERENCES}

Anti-Discrimination Act (2008). Official Gazette of the Republic of Croatia, 85. https://www. legislationline.org/documents/id/16572

Baetens P, Camus M and Devroey P (2002). Counselling lesbian couples: Requests for donor insemination on social grounds, Reproductive BioMedicine Online, 6 (1): 75-83. https://doi.org/10.1016/S1472-6483(10)62059-7

Baiocco R and Laghi F (2013). Sexual orientation and the desires and intentions to become parents, Journal of Family Studies, 19 (1): 90-98. https://doi.org/10.5172/jfs.2013.19.1.90

Berkowitz D and Marsiglio W (2007). Gay men: Negotiating procreative, father, and family identities, Journal of Marriage and Family, 69 (2): 366-381. https://doi.org/10.1111/ j.1741-3737.2007.00371.x

Bos HMW, van Balen F and van den Boom DC (2003). Planned lesbian families: Their desire and motivation to have children, Human Reproduction, 18 (10): 2216-2224. https://doi. org/10.1093/humrep/deg427

Braun V and Clarke V (2006). Using thematic analysis in psychology, Qualitative Research in Psychology, 3 (2): 77-101. https://doi.org/10.1191/1478088706qp063oa

Connidis IA and McMullin JA (2002). Sociological ambivalence and family ties: A critical perspective, Journal of Marriage and Family, 64 (3): 558-567. https://doi.org/10.1111/ j.1741-3737.2002.00558.x

European Union Agency for Fundamental Rights (2014). EU LGBT survey - European Union lesbian, gay, bisexual and transgender survey. Luxembourg: Publications Office of the European Union. https://doi.org/10.2811/37969

Freitas R and Testa MR (2017). Fertility desires, intentions and behaviour: A comparative analysis of their consistency (Working Papers 04/2017). Wien: Vienna Institute of Demography.

Goldberg AE, Downing JB and Moyer AM (2012). Why parenthood, and why now? Gay men's motivations for pursuing parenthood, Family Relations, 61 (1): 157-174. https:// doi.org/10.1111/j.1741-3729.2011.00687.x

Golombok S (2017). Parenting in new family forms, Current Opinion in Psychology, 15: 76-80. https://doi.org/10.1016/j.copsyc.2017.02.004

Hanzec Marković I and Štambuk M (2019). Parenthood motivation in emerging adulthood. Unpublished manuscript.

Hoffman LW and Hoffman ML (1973). The value of children to parents. In: Fawcett JT (ed). Psychological perspectives on population. New York: Basic Books, 19-76.

Hoffman LW, Thorton A and Manis JD (1978). The value of children to parents in the United States, Journal of Population, 1 (2): 91-131. https://doi.org/10.1007/BF01277597

Huić A, Jugović I and Kamenov Ž (2015). Stavovi studenata o pravima osoba homoseksualne orijentacije [Student attitudes toward the rights of homosexual persons], Revija za socijalnu politiku, 22 (2): 219-245. https://doi.org/10.3935/rsp.v22i2.1224

Jugović I, Pikić A and Bokan N (2007). Lesbians, Gays and Bisexuals in Croatia: How the Stigma Shapes Lives? In: Takács J and Kuhar R (eds). Beyond the Pink Curtain: Everyday Life of LGBT People in Eastern Europe. Ljubljana: Peace Institute, 345-363.

Kamenov Ž, Huić A and Jelić M (2019). Determinants of Attitudes toward Same-gender Parenting: The Effect of Traditional Gender Roles Attitudes, Croatian Sociological Review, 49 (2): 231-251. https://doi.org/10.5613/rzs.49.2.5 
Kranz D, Busch H and Niepel C (2018). Desires and intentions for fatherhood: A comparison of childless gay and heterosexual men in Germany, Journal of Family Psychology, 32 (8): 995-1004. https://doi.org/10.1037/fam0000439

Lampic C, Svanberg AS, Karlström P-O and Tydén T (2006). Fertility awareness, intentions concerning childbearing, and attitudes towards parenthood among female and male academics, Human Reproduction, 21 (2): 558-564. https://doi.org/10.1093/humrep/ dei367

Langdridge D, Connolly K and Sheeran P (2000). Reasons for wanting a child: A network analytic study, Journal of Reproductive and Infant Psychology, 18 (4): 321-338. https:// doi.org/10.1080/713683044

Landgridge D, Sheeran P and Connolly K (2005). Understanding the reasons for parenthood, Journal of Reproductive and Infant Psychology, 23 (2): 121-133. https:// doi.org/10.1080/02646830500129438

Larsen BW (2011). The Seeking Fatherhood Study: The Phenomenological Experience of Gay Male Couples Seeking Parenthood (Doctoral dissertation). http://commons.pacificu. edu/spp/372 (14 March 2018)

Lubbe C (2013). LGBT parents and their children: Non-Western research and perspectives. In: Goldberg AE and Allen KR (eds). LGBT-Parent families: Innovations in research and implications for practice. New York: Springer, 209-223. https://doi.org/10.1007/978-14614-4556-2_14

Maričić A, Štambuk M, Tadić Vujčić M and Tolić S (2016). Ja nisam gej mama, ja sam mama: roditeljstvo LGB osoba u Hrvatskoj [I'm not a gay mom, I'm a mom. Parenthood of LGB people in Croatia]. Zagreb: Jesenski i Turk.

Milković M (2013). Brutal reality: A study on anti-LGBTIQ violence, discrimination, and hate crime in Croatia. Zagreb: Zagreb Pride.

Miller WB and Pasta DJ (1996). Couple disagreement: Effects on the formation and implementation of fertility decisions, Personal Relationships, 3 (3): 307-336. https://doi. org/10.1111/j.1475-6811.1996.tb00119.x

Newton CR, Hearn MT, Yuzpe AA and Houle M (1992). Motives for parenthood and response to failed in vitro fertilization: Implications for counselling, Journal of Assisted Reproduction and Genetics, 9 (1): 24-31. https://doi.org/10.1007/BF01204110

Pew Research Center (2013). A suvey of LGBT Americans. https://www.pewsocialtrends. org/2013/06/13/a-survey-of-lgbt-americans/ (20 March 2018)

Rabin Al (1965). Motivation for parenthood, Journal of Projective Techniques and Personality Assessment, 29 (4): 405-413. https://doi.org/10.1080/0091651X.1965.10120230

Riggs DW, Power J and von Doussa H (2016). Parenting and Australian trans and gender diverse people: An exploratory survey, International Journal of Transgenderism, 17 (2): 59-65. https://doi.org/10.1080/15532739.2016.1149539

Riskind RG and Patterson CJ (2010). Parenting intentions and desires among childless lesbian, gay, and heterosexual individuals, Journal of Family Psychology, 24 (1): 78-81. https://doi.org/10.1037/a0017941

Stacey J (2006). Gay parenthood and the decline of paternity as we knew it, Sexualities, 9 (1): 27-55. https://doi.org/10.1177/1363460706060687

Stotzer RL, Herman JL and Hasenbush A (2014). Transgender parenting: A review of existing research. Los Angeles: The Williams Institute. 
Štambuk M, Tadić Vujčić M, Milković M and Maričić A (2019). Pathways to Parenthood among LGBTIQ People in Croatia: Who Wants to Become a Parent and How?, Croatian Sociological Review, 49 (2): 175-203. https://doi.org/10.5613/rzs.49.2.3

Štrbić M, Jeleković T, Popović D, Brajković M, Žukina P and Štambuk M (2019). Evaluations of Same-sex vs. Different-sex Couples' Parenting among Heterosexual University Students: Experimental Between-subjects Vignette Design Study, Croatian Sociological Review, 49 (2): 253-281. https://doi.org/10.5613/rzs.49.2.6

Švab A and Kuhar R (2005). The unbearable comfort of privacy - The everyday life of gays and lesbians. Ljubljana: Peace Institute.

Thompson R and Lee C (2011). Fertile imaginations: Young men's reproductive attitudes and preferences, Journal of Reproductive and Infant Psychology, 29 (1): 43-55. https:// doi.org/10.1080/02646838.2010.544295

Thornton A and Young-DeMarco L (2001). Four decades of trends in attitudes toward family issues in the United States: The 1960s through the 1990s, Journal of Marriage and Family, 63 (4): 1009-1037. https://doi.org/10.1111/j.1741-3737.2001.01009.x

Touroni E and CoyleA (2002). Decision-making in planned lesbian parenting: An interpretative phenomenological analysis, Journal of Community and Applied Social Psychology, 12 (3): 194-209. https://doi.org/10.1002/casp.672

Tydén T, Svanberg AS, Karlström P-O, Lihoff L and Lampic C (2006). Female university students' attitudes to future motherhood and their understanding about fertility, The European Journal of Contraception and Reproductive Health Care, 11 (3): 181-189. https://doi.org/10.1080/13625180600557803

Van Eeden-Moorefield B, Few-Demo AL, Benson K, Bible J and Lummer S (2018). A content analysis of LGBT research in top family journals 2000-2015, Journal of Family Issues, 39 (5): 1374-1395. https://doi.org/10.1177/0192513X17710284

Vučković Juroš T (2017). Comparing the outcomes of children of same-sex and oppositesex partners: Overview of the quantitative studies conducted on random representative samples, Croatian Sociological Review, 47 (1): 65-95. https://doi.org/10.5613/rzs.47.1.3

Vučković Juroš T (2019). "Why is it that here we can be a family, and there we cannot?" How Wider Socio-Institutional Frameworks Shape Experiences of LGB Parenting, Croatian Sociological Review, 49 (2): 205-229. https://doi.org/10.5613/rzs.49.2.4

Vučković Juroš T, Dobrotić I and Zrinščak S (2015). Socijalna distanca i društveno okruženje: Manjinske skupine u postkomunističkim i južnoeuropskim zemljama. In: Baloban $\mathrm{J}$, Nikodem K and Zrinščak S (eds). Vrednote u Hrvatskoj i u Europi: Komparativna analiza [Values in Croatia and in Europe: A Comparative Analysis]. Zagreb: Kršćanska sadašnjost, 217-257.

Weston R, Qu L, Parker R and Alexander M (2004). "It's not for lack of wanting kids...": A report on the Fertility Decision Making Project. Melbourne: Australian Institute of Family Studies. 


\title{
Motivacija za roditeljstvom kod LGBTIQ osoba u Hrvatskoj: razlozi zašto (ne) biti roditelj
}

\author{
Marina ŠTAMBUK
}

Zavod za menadžment i ruralno poduzetništvo Agronomskog fakulteta Sveučilišta u Zagrebu, Hrvatska

mstambuk@agr.hr

Marina MILKOVIĆ

Centar za socijalnu skrb Zagreb, Podružnica Gornji grad - Medveščak, Zagreb, Hrvatska

marinamilkovic88@gmail.com

\author{
Antonija MARIČIĆ \\ Zagreb, Hrvatska \\ antonija.maricic@gmail.com
}

\section{SAŽETAK}

Želje, namjere i motivacija za roditeljstvom temeljito su istraženi među heteroseksualnim parovima, ali su malobrojna istraživanja među lezbijkama, gejevima, biseksualnim, transrodnim, interspolnim i queer (LGBTIQ) osobama. Glavni cilj istraživanja bio je ispitati želju za roditeljstvom i različite razloge za i protiv roditeljstva među LGBTIQ osobama u Hrvatskoj. U internetskom anketnom istraživanju sudjelovalo je 486 LGBTIQ osoba koje nisu roditelji. Kvantitativni dio istraživanja obuhvaćao je mjere želje za roditeljstvom te razloga za i protiv roditeljstva, dok su u kvalitativnom dijelu analizirani odgovori na otvorena pitanja o dodatnim razlozima koji utječu na želju sudionika/ ca za ili protiv vlastitog roditeljstva. Rezultati su pokazali da $46 \%$ sudionika/ca želi postati roditeljima, $35 \%$ ne zna i $19 \%$ ne želi imati djecu. Glavni razlozi za roditeljstvo među sudionicima/cama koji žele imati djecu su internalni - želja za davanjem ljubavi, dijeljenjem znanja i razvijanjem posebne povezanosti s djetetom. Sudionici/e koji ne žele imati djecu također su naglasili internalne razloge protiv roditeljstva, kao što su ograničavanje osobne slobode, prevelika odgovornost i velika količina posla kao dio roditeljstva. U kvalitativnom dijelu uočen je niz dodatnih razloga za ili protiv roditeljstva. Neki su od razloga univerzalni, neovisni o seksualnoj orijentaciji i rodnom identitetu, dok neki razlozi reflektiraju brige vezane uz zakonska i društvena ograničenja s kojima se LGBTIQ osobe moraju suočiti kod ostvarivanja roditeljstva.

Ključne riječi: želja za roditeljstvom, razlozi za roditeljstvo, razlozi protiv roditeljstva, LGBTIQ osobe 
